followed by a normal ignition in the space of about one second.

The low-pressure flame has the following characteristics of a 'cool' flame: (i) pale blue and nonluminous; (ii) slow speed; (iii) small pressure pulse ; (iv) capacity to lead to a two-stage ignition ; (v) associated with peroxide and aldehyde formation.

Up to the present, however, attempts to produce similar flames artificially in cold gas mixtures with a feebly glowing platinum spiral have not met with any success.

Townend, in a study of the auto-ignition of ethylene/air mixtures ${ }^{1}$, found no evidence of cool flames despite exploration over a wide range of values of temperature, pressure and composition. Since the present study differs only from this work in composition, namely, a greater quantity of nitrogen for all ethylene concentrations, it seems likely that the diluent effect of the nitrogen is a vital factor in the formation of cool flames in ethylene.

These observations were made in the Fuel Depart. ment of the University of Leeds, and we wish to express our appreciation of the interest taken by Prof. A. L. Roberts in this work. A detailed account will be published in due course. We wish to thank the directors of the British Oxygen Company, Ltd., for permission to publish this letter.

J. R. Аввотт

British Oxygen Co., Ltd., Morden,

London, S.W.19.

${ }^{1}$ Kane and Townend, Proc. Roy. Soc., A, 160, 174 (1937).

\section{Mode of Decomposition of Sulphur Sesquioxide}

Wöhler and Wegwitz ${ }^{1}$ tentatively assumed the formation of sulphur monoxide as an unstable intermediate compound in the decomposition of sulphur sesquioxide and thus accounted for the formation of thiosulphate and polythionates. Neither Partington and $\mathrm{Vogel}^{2}$ nor Wöhler and Wegwitz obtained sulphur monoxide during the decomposition.

While studying the properties of sulphur sesquioxide, I heated a sample of the sesquioxide in an allglass apparatus at $60^{\circ} \mathrm{C}$. The volatile products of decomposition, when cooled in a U-tube immersed in liquid air, condensed to a pale yellow solid. On shaking with cold dilute alkali, this yellow residue gave rise to sulphide, sulphite, thiosulphate and sulphur.

When sulphur monoxide prepared by the combustion of sulphur in oxygen at low pressure (Schenk ${ }^{3}$ ) is cooled at the temperature of liquid air, a similar yellow condensate is obtained. On hydrolysis with cold dilute alkali the condensate gives rise to sulphide, sulphite, thiosulphate and sulphur, as in the case of the products of decomposition of sulphur sesqui. oxide mentioned above. It is thus concluded that the condensates in the two cases are the same. In other words, this experiment shows that the sulphur monoxide is produced during the decomposition of sulphur sesquioxide. It may be mentioned that the formation of the products of alkali hydrolysis has been explained by B. S. Rao on the basis that disulphur monoxide is produced during the decomposition of sulphur monoxide.

Further support for this observation comes from the following experiment. When sulphur trioxide is led into a solution of sulphur in dry carbon tetrachloride, a dark blue solution of the sesquioxide is obtained. On subjecting this to alkali hydrolysis, it is noticed that sulphide, sulphite, thiosulphate and sulphur are produced. No detectable amounts of polythionates are formed. The production of sulphide during the hydrolysis of sulphur sesquioxide has been observed for the first time, and this is attributed to the production of sulphur monoxide as the primary product during the hydrolysis. The results of a representative experiment are :

\begin{tabular}{|c|c|c|c|c|c|}
\hline \multirow{2}{*}{$\begin{array}{l}\text { Amount of } \\
\text { sulphur } \\
\text { (mgm.) in } \\
\text { carbon tetra- } \\
\text { chloride } \\
(80 \mathrm{gm} .)\end{array}$} & \multirow{2}{*}{$\begin{array}{l}\text { Sulphur } \\
(\text { mgm.) as } \\
\text { SO a added } \\
\text { ro carbon } \\
\text { tetra- } \\
\text { chloride }\end{array}$} & \multicolumn{4}{|c|}{ Products $\begin{array}{c}\text { of alkali hydrolysis } \\
\text { (in mgm.) }\end{array}$} \\
\hline & & $\begin{array}{l}\text { Sulphur } \\
\text { as } \\
\text { sulph- } \\
\text { ide }\end{array}$ & $\begin{array}{l}\text { Sulphur } \\
\text { as } \\
\text { sulph. } \\
\text { ite }\end{array}$ & $\begin{array}{l}\text { Sulphwr. } \\
\text { as thio- } \\
\text { sulph- } \\
\text { ate }\end{array}$ & $\begin{array}{c}\text { Free } \\
\text { sulphur }\end{array}$ \\
\hline $97 \cdot 92$ & 97.92 & $18 \cdot 2$ & $99 \cdot 2$ & $36 \cdot 8$ & $40 \cdot 9$ \\
\hline
\end{tabular}

It is presumed that sulphur sesquioxide can decompose in two ways :

$$
\begin{aligned}
& \text { (i) } \mathrm{S}_{2} \mathrm{O}_{3} \longrightarrow \mathrm{S}+\mathrm{SO}_{3} \\
& \text { (ii) } \mathrm{S}_{2} \mathrm{O}_{3} \longrightarrow \mathrm{SO}_{2}+\mathrm{SO} \text {. }
\end{aligned}
$$

The amount of sulphur monoxide produced can be calculated quantitatively from the products of alkali hydrolysis by the method developed by B. S. Rao4. It has been found in this case that 82 per cent of the decomposition of sesquioxide goes according to reaction (ii). This value is in good agreement with the percentage ( 80 per cent) obtained by the German authors. It can therefore be concluded that sulphur monoxide is one of the primary products of decomposition of sulphur sesquioxide.

Further details of the work will be published elsewhere.

I wish to express my thanks to Dr. B. Sanjiva Rao and Dr. M. R. Aswathanarayana Rao for their interest in this work.

\section{A. R. Vasudeva Murthy}

Department of Pure and Applied Chemistry, Indian Institute of Science,

Bangalore 3.

1 Wöhler and Wegwitz, $Z$. anorg. Chem., 213, 129 (1933).

2 Partington and Vogel, $J$. Cnem. Soc., 127, 1514 (1925). Partington. Nature, 164, 467 (1949).

${ }^{3}$ Schenk, P. W., Z. anorg. allg. Chem., 220, 260 (1935).

- Sanjiva Rao, B., Proc. Ind. Acad. Sci., 10. 491 (1939).

\section{Paper Chromatography of Nicotinic Acid Derivatives}

LeIfer et al. ${ }^{1}$ have reported the paper chromatography of nicotinic acid with the use of microbiological assay. While our work was in progress, Huebner ${ }^{2}$ described a spot test for detection of some pyridine derivatives. The present work describes sensitive qualitative techniques developed in this Laboratory for the detection of tertiary and quaternary pyridinium compounds. The laborious procedure involved in the microbiological method of Leifer et al. ${ }^{1}$ is obviated by rapid colour or fluorescent tests. For the colour test, advantage was taken of König's ${ }^{3}$ reaction, namely, the formation of coloured compounds when tertiary pyridine derivatives are treated with cyanogen bromide and a primary aromatic amine. The fluorescence test allows the detection of quaternary nicotinamide derivatives. Use is made of the formation of bluish-white fluorescent substances when quaternary pyridine compounds with 